University of Nebraska - Lincoln

DigitalCommons@University of Nebraska - Lincoln

1988

\title{
THE ORIGIN OF CHUBUTOLITHES IHERING, ICHNOFOSSILS FROM THE EOCENE AND OLIGOCENE OF CHUBUT PROVINCE, ARGENTINA
}

Thomas M. Bown

U.S. Geological Survey, Denver, Colorado

Brett C. Ratcliffe

University of Nebraska-Lincoln, bratcliffe1@unl.edu

Follow this and additional works at: https://digitalcommons.unl.edu/entomologypapers

Part of the Entomology Commons

Bown, Thomas M. and Ratcliffe, Brett C., "THE ORIGIN OF CHUBUTOLITHES IHERING, ICHNOFOSSILS FROM THE EOCENE AND OLIGOCENE OF CHUBUT PROVINCE, ARGENTINA" (1988). Papers in Entomology. 137.

https://digitalcommons.unl.edu/entomologypapers/137

This Article is brought to you for free and open access by the Museum, University of Nebraska State at DigitalCommons@University of Nebraska - Lincoln. It has been accepted for inclusion in Papers in Entomology by an authorized administrator of DigitalCommons@University of Nebraska - Lincoln. 


\title{
THE ORIGIN OF CHUBUTOLITHES IHERING, ICHNOFOSSILS FROM THE EOCENE AND OLIGOCENE OF CHUBUT PROVINCE, ARGENTINA
}

\author{
THOMAS M. BOWN AND BRETT C. RATCLIFFE \\ U.S. Geological Survey, Denver, Colorado 80225 and \\ University of Nebraska State Museum, Lincoln 68588
}

\begin{abstract}
The distinctive trace fossil Chubutolithes gaimanensis $\mathrm{n}$. ichnosp. occurs in Casamayoran (early Eocene) and Colhuéhaupian (late Oligocene) alluvial rocks of the Sarmiento Formation in eastern Chubut Province, Argentina. Though known for nearly 70 years, its origin has remained obscure. Examination of new specimens and comparisons with modern analogs demonstrate that specimens of Chubutolithes represent the fossil nests of a mud-dauber (Hymenoptera: Sphecidae). Virtually identical nests are constructed today by mud-daubers in areas as disparate as southern Santa Cruz Province, Argentina, and Nebraska, confirming that quite similar trace fossils can be produced by several different taxa in a higher taxonomic clade. No satisfactory ethological term exists for trace fossils that, like Chubutolithes, were constructed by organisms above, rather than within, a substrate or medium. The new term aedificichnia is proposed.

Chubutolithes occurs in alluvial paleosols and is associated with a large terrestrial ichnofauna. These trace fossils include the nests of scarab beetles, compound nests of social insects, and burrows of earthworms.
\end{abstract}

\section{INTRODUCTION}

$C_{1}$ HUBUTOLITHES IS a name coined by Ihering (1922) for small, enigmatical fossils found by him in Eocene rocks of Patagonia, Argentina. Specimens of Chubutolithes were originally described (but not named) by Windhausen (1921) from their type locality, just west of the town of Gaiman, Chubut Province (Figure 1). Additional specimens were soon discovered in the "formación Patagonia," north of Comodoro Rivadavia, by Schiller (1925, fig. 1), who was the first to figure them. Although he gave a scientific name to his finds, Ihering (1922) provided no specific designation, considering them to be the remains of an unknown invertebrate.

Chubutolithes has been known in Argentina for well over half a century; however, there has been no consensus about its origin. Windhausen (1921) believed it to be a mammal coprolite; however, Schiller (1925, p. 36) was very impressed by the fine detail of the surface structure, which is faithfully reproduced in every specimen. He stressed that the structure is an extremely notable problematic form that he and his colleagues were unable to explain. After more reflection, Schiller thought it possible that it was a "trace" of a coelenterate. Like Windhausen, Frenguelli (1927, p. 239) also found Chubutolithes in the section at Gaiman and believed that it represents the internal mold of a cavity produced by some "inferior" organism that could have been a coelenterate, or possibly a tunicate.

Simpson (1935, p. 13-15) provided the first detailed description of Chubutolithes and, although he was reluctant to speculate about its origin, he observed (p. 15) that they ". . . probably are organic in at least a broad sense of the word." Simpson also first detailed the stratigraphic occurrence of the fossil, recording that it is abundant in his (1935, p. 13 and fig. 3) "Section 2, stratum h" near Gaiman (Simpson's Gaiman Nuevo). Both Windhausen (1921) and Frenguelli (1927) observed that Chubutolithes at Gaiman was found associated with a nodular bed ("bancos con nodulos" and "los bancos de Chubutolithes," respectively-see Figure 2, this paper), a fact not explicitly stated by Simpson but almost certainly observed by him. The occurrence of Chubutolithes at Gaiman was also noted parenthetically by Bordas (as “chubutolites," 1937, p. 217).

Simpson (1935) was able to document that all specimens of Chubutolithes known during the time of his study (those from near Comodor Rivadavia and from Gaiman) occur only in rocks of Casamayoran (early Eocene) age, and not in the considerably younger (Miocene) "Patagonian" sensu stricto as thought by Schiller (1925). In the Gaiman area, these rocks are currently included in the Pan de Azúcar Member of the Sarmiento Formation (Mendia and Bayarsky, 1981). One specimen is now known from the Trelew Member of the Sarmiento Formation (Colhuéhaupian = late Oligocene).

In the course of geologic investigations in the Gaiman area in 1983 and 1987, Bown obtained several specimens of this fossil from its type locality on the Pan de Azúcar (Simpson, 1935, figs. 3, 4), and concluded that it is almost certainly a trace fossil. Further studies by both of the authors confirm this determination and offer a solution to its origin. Because Chubutolithes is a very distinctive form that is quite abundant locally in rocks of Casamayoran age, and because the name Chubutolithes has long priority, this trace fossil is given a new ichnospecific name, but Ihering's (1922) designation is retained as the ichnogeneric name.

Abbreviations for institutions are: MACN, Museo Argentino Ciencias Naturales "Bernardino Rivadavia," Buenos Aires; USGS, U.S. Geological Survey, Denver, Colorado.

\section{SYSTEMATIC PALEONTOLOGY}

Ichnogenus CHubutolithes Ihering, 1922

Type species. - Chubutolithes gaimanensis n. ichnosp., type and only known ichnospecies.

Diagnosis.-Cylindrical to fusiform compound structures, roughly $3-7 \mathrm{~cm}$ in length by $1.5-4.5 \mathrm{~cm}$ wide; made up of one to several hemicylindrical cells adjacent and parallel to one another; one side unstructured, other side exhibits from one to several superficial parallel grooves, parallel to the long axes of the cells and partitioning the compound specimen into two or more raised, curvilinear cells; between the transverse lines, and forming relief on the raised cells, a second pattern consists of a series of intersecting curvilinear lines that, though curved, are tangentially perpendicular to the long axes of the cells; these lines are also incuse, and numerous small, lozenge-shaped areas between them and bounded by their intersections are slightly raised in relief; a few well-preserved specimens exhibit a partlyfilled aperture, about $5 \mathrm{~mm}$ in diameter, to one side of one end of the long axis (dorsally); interiors of cells unstructured. 


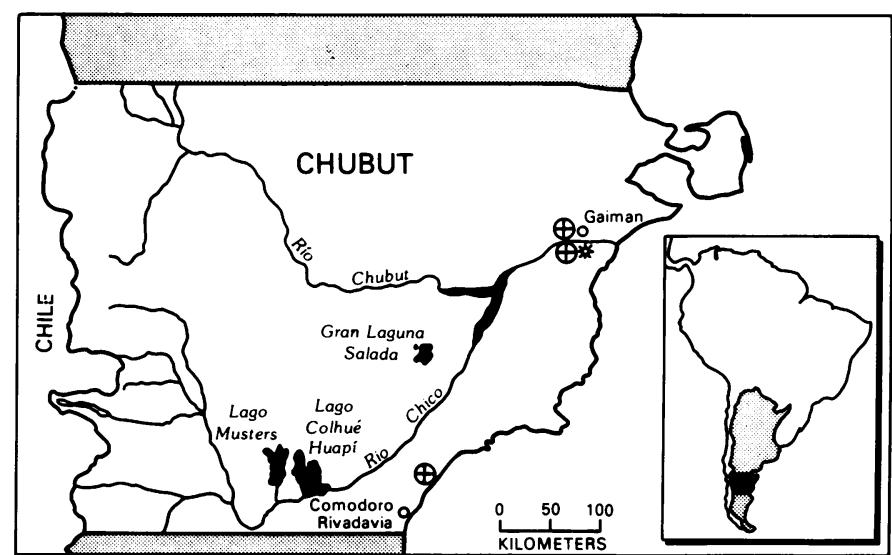

FIGURE 1-Map of Chubut Province, Argentina, showing Eocene (crossed circles) and Oligocene (starred) localities yielding Chubutolithes gaimanensis $\mathrm{n}$. ichnosp.

\section{Chubutolithes gaimanensis $\mathrm{n}$. ichnosp.}

Figures 3, 4

Etymology. - After the village of Gaiman, Chubut Province, near the type locality.

Holotype.-MACN CH 1010 (Figures 3.3, 4.3).

Hypodigm. - The type specimen, USGS numbers 22618 (Figures 3.1, 4.2), 22619 (Figure 3.5), 22621 (Figure 3.2), 22622 (Figure 3.4), 22623 (Figure 3.6), 22624 (Figure 4.1), and about one hundred uncatalogued specimens in the MACN collection.

Type locality. - Pan de Azúcar (Simpson, 1935, fig. 4; Bown and Powers, in press, fig. 6), about $1 \mathrm{~km}$ west of Gaiman, Provincia de Chubut, Republic of Argentina. Specimens are from "Section 2, stratum h" of Simpson (1935, fig. 3), about $4 \mathrm{~m}$ below the top of the Pan de Azúcar Member of the Sarmiento Formation. Pan de Azúcar (Simpson, 1935, fig. 4; Bown and Powers, in press, fig. 6), about $1 \mathrm{~km}$ west of Gaiman, Provincia

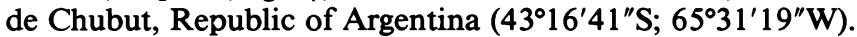

Distribution. -Casamayoran (early Eocene): 1) type locality; 2) an identical level about $500 \mathrm{~m}$ east of the Pan de Azúcar (Bordas, 1937); 3) $4 \mathrm{~m}$ beneath top of Unit 7 of Pan de Azúcar Member of Sarmiento Formation on south side of Rio Chubut, opposite Bryn Gwyn, Chubut (Bown and Powers, in press, figs. $3,8)$; 4) Casamayoran part of Sarmiento Formation north of Comodoro Rivadavia, Chubut, near Bahía Solano (Schiller, 1925). Colhuéhaupian (late Oligocene): 5) base of Trelew Member of Sarmiento Formation, Unit 10 of section taken near Bryn Gwyn, Chubut (Bown and Powers, in press, figs. 3, 8). At the type locality and at locality 2 above, the specimens clearly occur in a calcrete intraclastic conglomerate.

Diagnosis. - Only known ichnospecies; same as for ichnogenus.

Discussion. - Chubutolithes gaimanensis is indeed an intriguing fossil; its extremely complicated surface ornamentation (Figures 3,4$)$ is, as Simpson $(1935$, p. 14, paraphrasing Windhausen, 1921, p. 26) observed: “. . . much as if a feather had been wound around the nodule." The replication of this intricate ornamentation in all specimens of Chubutolithes is enough to suggest biogenic origin. The size range of specimens in also relatively constant, too much so for them to be inorganic. Naturally, however, specimens preserving only a few cells vary in size and shape from those preserving more chambers (the maximum number of chambers observed is six, and the minimum, two). Similarly, the filled or partly filled aperture seen on some of the more complete specimens is taken to be representative of the structure. No specimens are known with more than one aperture

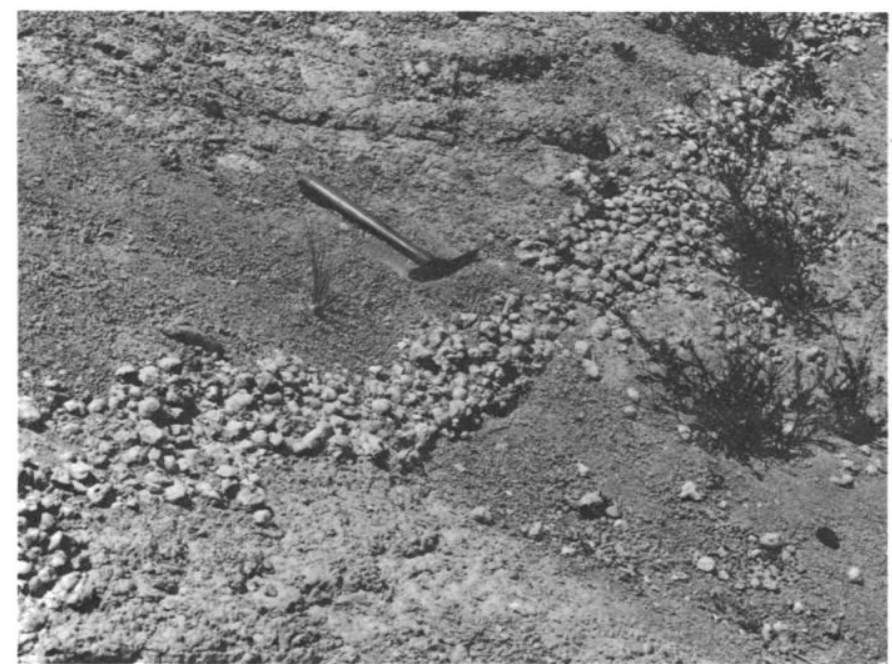

FIGURE 2-Exposure of Chubutolithes gaimanensis-bearing intraclastic calcrete conglomerate on the Pan de Azúcar, about $1 \mathrm{~km}$ west of the town of Gaiman, Chubut Province. Conglomerate lies about $4 \mathrm{~m}$ beneath the top of the Pan de Azúcar Member of the Sarmiento Formation (Casamayoran $=$ early Eocene).

preserved, and this is invariably (six specimens seen) situated dorsally on one of the lateral cells and with the aperture pointed in the direction of convexity of the sub-pattern of intersecting curvilinear incuse lines (Figures 3.1, 3.5, 4.2).

The complex incuse line ornamentation on specimens of $\mathrm{Chu}$ butolithes is clearly surficial and has commonly been emphasized by weathering. Thin sections reveal the interiors to be structureless, and artificial acid weathering of the structures caused the pattern to be less and less distinct the more the specimens were treated. Simpson $(1935$, p. 14) observed that the ornamentation sometimes covers the specimens completely. Of more than 100 collected specimens and several hundred others examined in the field, Bown saw none such as Simpson described; however, two examples of deformed specimens and one example of two individual specimens joined by carbonate cement were seen. In all of these, deformation of the specimens made the pattern appear to be present, or partially present, on both sides.

Grain size and major oxide analyses of specimens of Chubutolithes demonstrate that they were constructed of calcareous silty mud, commonly with an admixture of very fine tuffaceous sand. This composition is nearly identical to that of the enclosing sediment, with the exception that the trace fossils contain a higher percentage of carbonate. Because the fossils occur in an immature mollic paleosol, it is likely that the calcareous cement is pedogenic in origin, although formed at a different time than that composing the calcrete intraclasts.

In the field in the Gaiman area, specimens of Chubutolithes occur in a calcrete conglomerate (Figure 2), but one that was probably reworked by fluvial action, judging both from the roundness of the calcrete glaebules and their association with mud intraclasts and a considerable amount of fine-medium sand. The orientation of Chubutolithes within this conglomerate is wholly haphazard. Specimens with long axes flat against bedding are no more common than those with long axes perpendicular or inclined to bedding.

In the Pan de Azúcar Member of the Sarmiento Formation, the unit yielding Chubutolithes is associated with superjacent and subjacent paleosols yielding numerous trace fossils of terrestrial organisms. These include a wide variety of rhizoliths, 

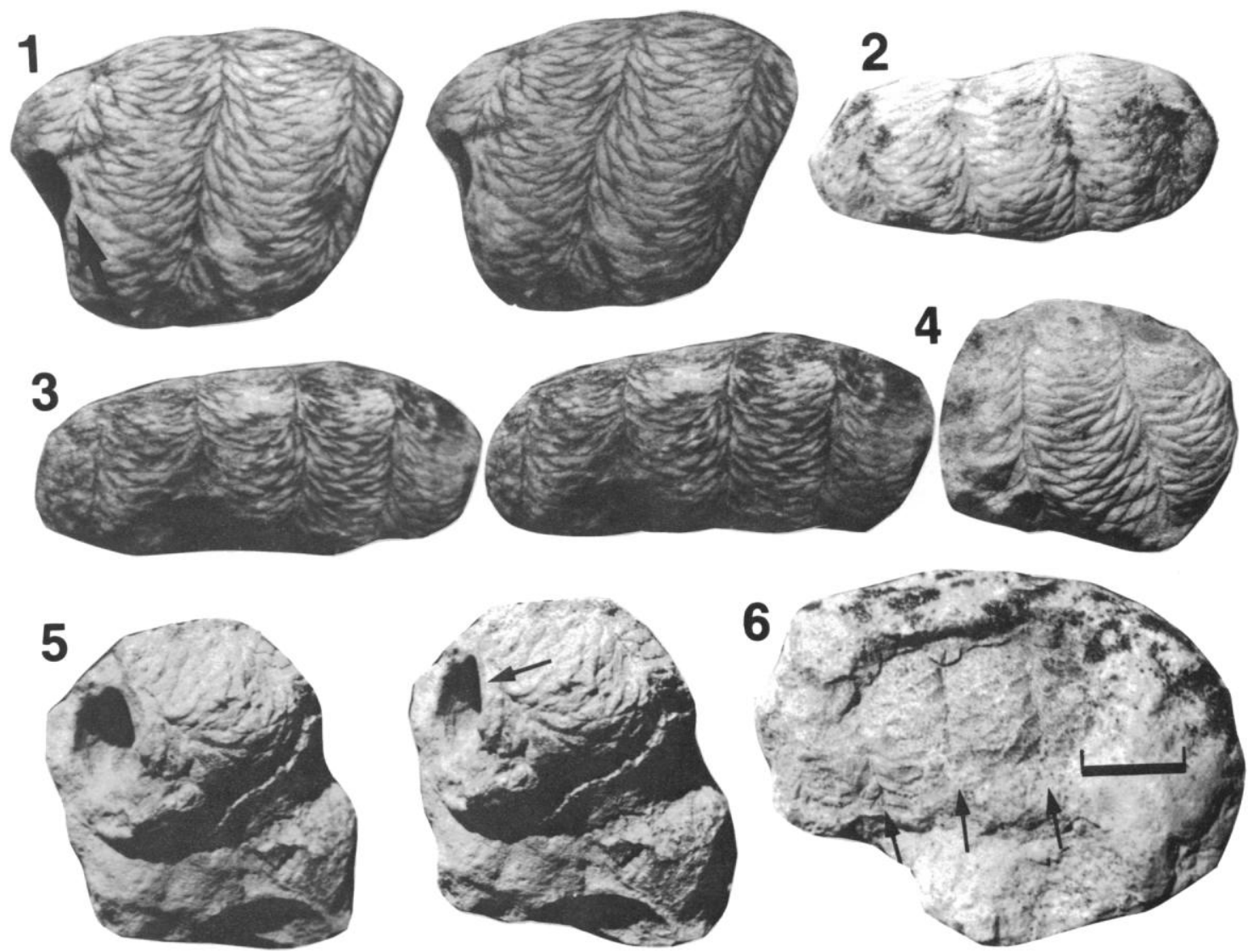

Figure 3-Chubutolithes gaimaneisis n. ichnosp. from the Pan de Azúcar Member of the Sarmiento Formation; Pan de Azúcar, near Gaiman. 1, USGS 22618, ink-stained to enhance ornamentation and showing entrance aperture (arrow); 2, USGS 22621, natural specimen; 3, MACN CH 1010 (type specimen), ink-stained to enhance ornamentation; 4, USGS 22622, natural specimen; 5, USGS 22619, showing entrance aperture; 6 , USGS 22623, specimen partly exposed from $\mathrm{CaCO}_{3}$ encrustation, showing transverse incuse lines separating chambers. Bar in 6 is $1 \mathrm{~cm}$; all to same scale. 1,3 , and 5 are stereophotographs.

nests of scarabeid beetles (e.g., Frenguelli, 1938, 1939), and compound nests of subterranean social insects, probably of ants or termites (Bown and Powers, in press). In the Trelew Member, the solitary specimen is directly associated with cf. Edaphichnium, an earthworm ichnofossil (Bown and Kraus, 1983).

\section{ORIGIN OF CHUBUTOLITHES}

As reconstituted from all the available evidence, Chubutolithes is a biogenic structure that was constructed with mud. Originally these structures consisted of several curved, parallel, hemicylindrical cells attached together along their long axes, and attached during use to an unknown substrate. The observed specimens consist of two to six cells, but the authors assume that structures with more cells or one cell might have been constructed. That these cells were hollow during use is indicated by the dorsal apertures which led into them, and the surface ornamentation shows that they were constructed with mud and are not casts of burrows or other structures built in mud.

The long, incuse lines parallel to the long axes of the cells are surface expressions of the boundaries of the individual interior chambers, whereas the shorter, curvilinear, and joined incuse lines on the exteriors of the chambers represent traces of chamber-building activity. All of the surficial ornamentation comprises the bioglyph; i.e., "the ornament resulting from the inherent life activity of the trace-making organism" (Bromley et al., 1984, p. 494).

During 1987 fieldwork on the Atlantic coast at Monte León in southern Santa Cruz Province, Bown discovered a modern example of a structure virtually identical to Chubutolithes attached to a cobble lying on an exposure of the Miocene Santa Cruz Formation. Unfortunately, this extremely fragile structure was damaged irreparably in attempting to return it to the laboratory. The broken specimen contained six green larvae. These were forwarded to Ratcliffe, together with figures of Eocene Chubutolithes and descriptions of the occurrence of the modern Argentine example.
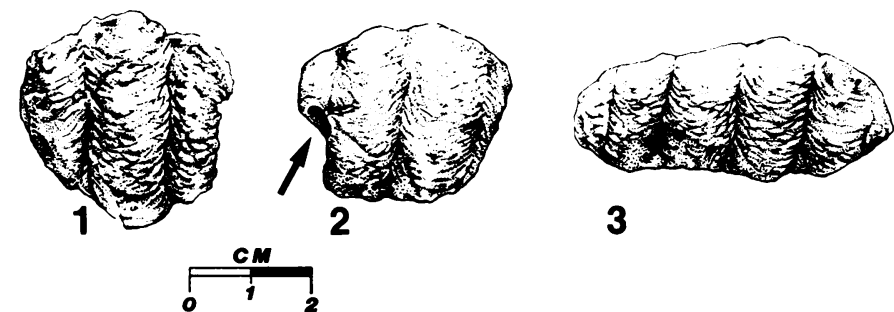

3

FIGURE 4-Chubutolithes gaimanensis n. ichnosp. from the Pan de Azúcar Member of the Sarmiento Formation; Pan de Azúcar, near Gaiman. 1, USGS 22624, a large specimen preserving three chambers; 2,USGS 22618, a large specimen with entrance aperture (arrow) and two chambers preserved, showing details of surface ornamentation; 3, MACN CH 1010 (type specimen), preserving five chambers and showing detail of surface ornamentation. 


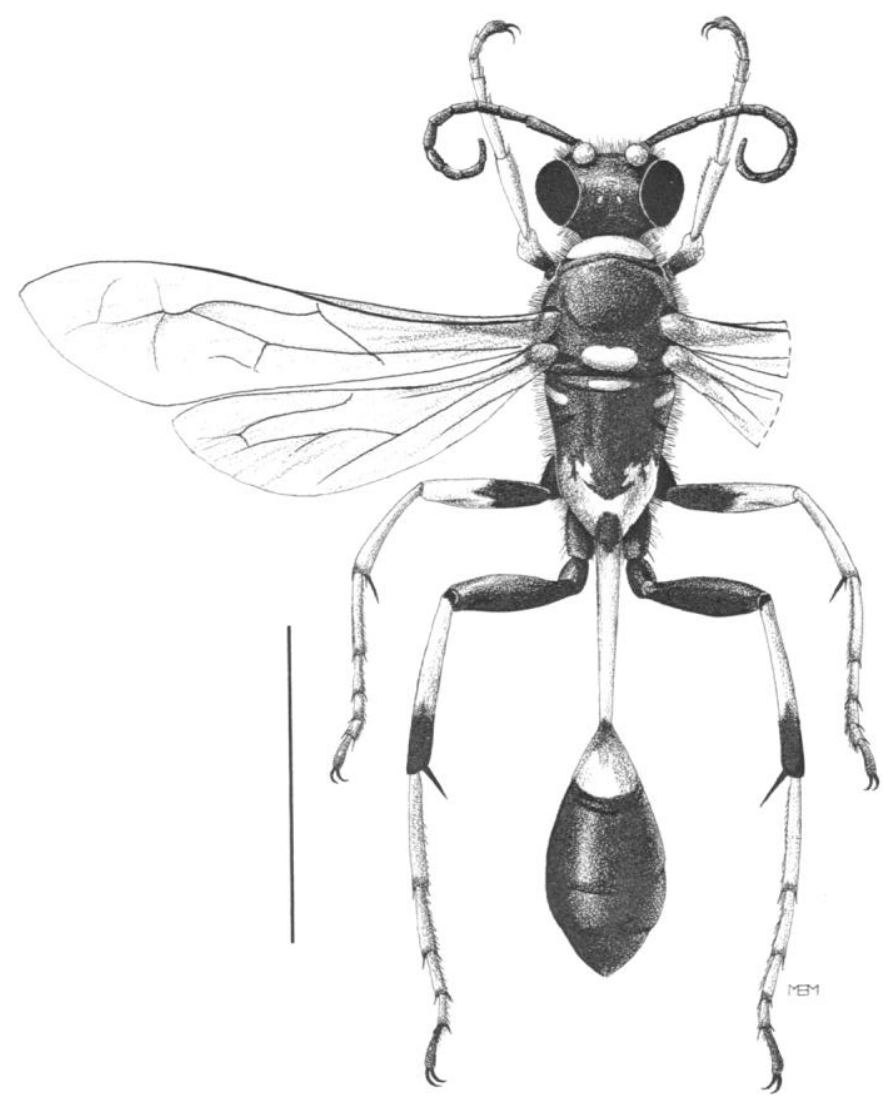

FIGURE 5-The extant mud-dauber Sceliphron caementarium, responsible for construction of mud nests similar in structure to the ichnofossil Chubutolithes gaimanensis. Bar is $1.0 \mathrm{~cm}$.

To an entomologist, Chubutolithes is immediately recognizable as the fossil nest of a mud-dauber. Mud-daubers (Figure 5) are wasps (Insecta: Hymenoptera). The most common muddaubers are found in the family Sphecidae, or the thread-waisted wasps (so-called because of the narrow juncture between the thorax and abdomen). Sphecids are solitary wasps whose nesting habits range from digging nests in the soil (the majority) to utilizing pre-existing cavities in wood or the ground. Some (the mud-daubers) construct nests on the vertical sides or undersurfaces of overhangs on earthen or stone edifices or on natural outcrops. The fact that concentrations of Chubutolithes are associated in a bed of stream-rounded calcrete glaebules and mud intraclasts in the Pan de Azúcar Member of the Sarmiento Formation suggests that these fossil nests may have been constructed on mud bank overhangs along a stream over some period of time. At various times, they were introduced into the stream bedload by natural weathering and/or periodic bank collapse.

Figure 6 illustrates the mud nests of Sceliphron caementarium (Drury) (Sceliphroninae), a wasp that occurs widely from Canada through Central America and the West Indies. These mud nests are constructed by the adult wasps, which carry small globules of mud to a sheltered area. Using their mandibles and legs they deposit and manipulate the globules, layer by layer, until they have constructed an elongate, tubular cell. This activity requires many trips by the adult to the mud source, which may be located some distance away. Each cell is formed on a relatively flat (usually vertical) substrate. When the nest "weathers out" or breaks away from the substrate, it has one flat, smooth surface; this is the surface that was against the substrate and not built up by the wasp during construction. This explains why the ornamentation is confined to one side in Chubutolithes. One to several cells are constructed adjoining one another along the long axis of the compound nest. The cells are provisioned with various kinds of insects or spiders that the adult captures. Normally the species of a genus or higher category prey upon species of only one group (Krombein, 1979). Mass provisioning or progressive provisioning of prey organisms may be practiced, depending on the species of wasp involved. Prey are paralyzed, but not killed, and serve as food for the developing wasp larva that hatches from an egg deposited in the provisioned cell.

Both authors have recently found modern mud-dauber nests: Bown in Santa Cruz Province, Argentina, and Ratcliffe in Nebraska. The mud nests in both cases were virtually identical with Chubutolithes. The cells of the Argentine nest were mass provisioned with the small, green larvae of a moth (Lepidoptera). The modern nests from Argentina and Nebraska, as well as others of this form from other parts of the world, are congeneric with Chubutolithes. The modern makers of these cells, however, comprise several different genera of wasps. This emphasizes one of the conclusions of Ratcliffe and Fagerstrom (1980) that there is a remarkable convergence in lebensspuren morphology among taxonomically dissimilar insects. One can proceed only so far down the taxonomic hierarchy in postulating the maker of a modern analog; after that point, resolution becomes impossible. In the case presented here, however, it is clear that the modern analog to Chubutolithes is a nest made by a wasp in the family Sphecidae.

\section{ETHOLOGICAL CLASSIFICATION OF CHUBUTOLITHES}

Although it is a form of nest, and thereby might be classified ethologically with other dwelling trace fossils as domichnia (e.g., Seilacher, 1953; Frey, 1971; Simpson, 1975), Chubutolithes is an edifice built upon rather than within a substrate and wholly constructed from raw materials extraneous to it. This type of structure differs appreciably from the original definition of domichnia, as well as from the intent of that definition which, as judged by current usage, means "burrows" or "dwelling tubes" (see Seilacher, 1953; Simpson, 1975). The new term aedificichnia is proposed for discrete, generally full relief(Seilacher, 1964) trace fossils that were constructed by organisms from raw materials. The word is derived from the Latin aedificium, meaning "building." This term, and its definition, is specifically meant to exclude all burrows or cavities excavated in a medium, as well as all burrows or trails on a medium surface.

Future classification problems are envisioned for trace fossils in which edifices constructed from raw materials are actually replaced through mineralization (for example, carton nests of insects), or in which nest or other structures constructed underground with carton are destroyed but the form of the structure is preserved by cavity filling. The fossil nests of Egyptian termites (Bown, 1982), and Argentine termites and/or ants (Bown and Powers, in press), may pose such a problem; however, it is perhaps best to retain these as domichnia for the present.

\section{ACKNOWLEDGMENTS}

We are grateful to D. W. Boyd and J. G. Fleagle for review of this paper and to D. W. Boyd, R. G. Bromley, J. G. Fleagle, and G. G. Simpson for discussion. The specimens of Chubutolithes gaimanensis described here were recovered on joint expeditions of the Museo Argentino Ciencias Naturales (Buenos Aires) and the State University of New York. We thank J. F. Bonaparte and M. F. Soria for museum support during field investigations, and acknowledge support of National Science Foundation grants BNS-82-10949 and BNS-86-06796, and grants from the National Geographic Society and L. S. B. Leakey 

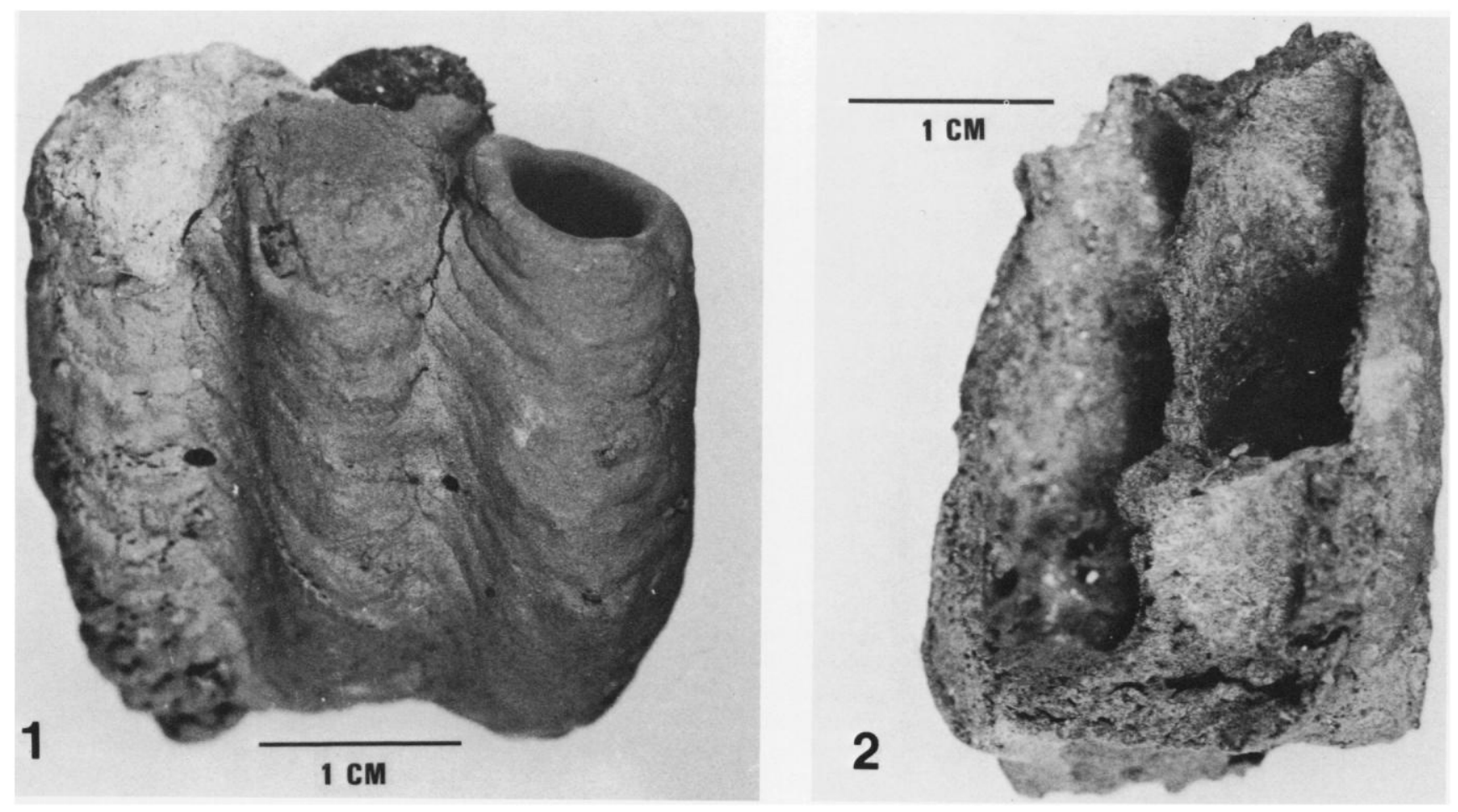

FIGURE 6-Mud nests of the extant mud-dauber Sceliphron caementarium from Nebraska. 1, entire nest consisting of three chambers; 2, sagittal section of nest with two chambers.

Foundation to J. G. Fleagle. Figures 4 and 5 were skillfully executed by M. C. Leggitt and M. Marcuson, respectively.

\section{REFERENCES}

Bordas, A. F. 1937. El afloramiento de Casamayor. "Gaea"; Anales de la Sociedad Argentina de Estudios Geograficos, V:215-220.

Bown, T. M. 1982. Ichnofossils and rhizoliths of the nearshore fluvial Jebel Qatrani Formation (Oligocene), Fayum Province, Egypt. Palaeogeography, Palaeoclimatology, Palaeoecology, 40:255-309.

-, AND M. J. KRAUS. 1983. Ichnofossils of the alluvial Willwood Formation (lower Eocene), Bighorn Basin, northwest Wyoming, U.S.A. Palaeogeography, Palaeoclimatology, Palaeoecology, 43:95-128.

- AND D. W. POWERS. In press. Paleoenvironments and geologic history of the Sarmiento Formation (Eocene-Oligocene), eastern Rio Chubut valley and Pampa de Gan Gan, Chubut Province, Argentina. Palaeogeography, Palaeoclimatology, Palaeoecology.

Bromley, R. G., S. G. Pemberton, AND R. A. Rahmani. 1984. A Cretaceous woodground: the Teredolites ichnofacies. Journal of $\mathrm{Pa}$ leontology, 58:488-498.

Frengueli, J. 1927. El entrerriense de Golfo Nuevo en El Chubut. Boletín de la Academia Nacional de Ciencias Córdoba, 29:191-270.

- 1938. Bolas de escarabeidos y nidos de véspidos fósiles. Revista Sociedad Argentino Ciencias Naturales, 12:348-351.

- 1939. Nidos fósiles de insectos. Notas del Museo de La Plata, 4:379-402.

FrEY, R. W. 1971. Ichnology - the study of fossil and recent lebensspuren, p. 91-125. In B. F. Perkins (ed.), Trace Fossils, a Field Guide. Louisiana State University School of Geosciences Miscellaneous Publications 71-1.
IHERING, H. voN. 1922. (Untitled). Palaeontologisches Zeitschrift, IV: 113.

Krombein, K. V. 1979. Superfamily Sphecoidea, p. 1573-1740. In K. V. Krombein, P. D. Hurd, Jr., D. R. Smith, and B. D. Burks (eds.), Catalog of Hymenoptera in America North of Mexico, Vol. 2. Smithsonian Institution Press, Washington, D.C.

MendiA, J. E., AND A. BAYARSKY. 1981. Estratigrafía del Terciaro en el valle inferior del Río Chubut. VIII Congres Geologia Argentino (San Luis), Actas III:593-606.

RATClifFe, B. C., AND J. A. FAGERSTROM. 1980. Invertebrate lebensspuren of Holocene floodplains: their morphology, origin, and paleoecological significance. Journal of Paleontology, 54:614-630.

SCHILlER, W. 1925. Estratigrafia, tectónica y petróleo de Comodoro Rivadavia (Chubut). Anales del Museo de La Plata, II:9-56.

SeILACHER, A. 1953. Studien zur Palichnologie. I. Über die Methoden r Palichnologie. Neues Jahrbuch für Geologischichte und Paläontologie Abhandlungen, 96:421-452.

- 1964. Sedimentological classification and nomenclature of trace fossils. Sedimentology, 3:253-256.

SimPSON, G. G. 1935. Early and middle Tertiary geology of the Gaiman region, Chubut, Argentina. American Museum Novitates, 775:1-29.

SimpSon, S. 1975. Classification of trace fossils, p. 39-54. In R. W. Frey (ed.), The Study of Trace Fossils. Springer-Verlag, New York.

WINDHAUSEN, A. 1921. Sobre un viaje de reconocimiento geológico en la parte Nordeste del Territorio del Chubut, con referencia especial a la cuestion de la provision de agua de Puerto Madryn. Ministerio de Agricultura de La Nación, Dirección General de Minas, Geológia e Hidrológia, Boletín 24(B):1-72.

ACCEPTED 23 SEPTEMB::R 1987 